\title{
Comparison of the heat for rectangular and circle salt boiling stove in Ban Dung area, Udon Thani Province.
}

\author{
Aphichat Srichat $^{1, *}$, Ponthep Vengsungnle ${ }^{2}$, Kaweepongt Hongtong ${ }^{1}$, Weeraphon Kaewka ${ }^{1}$ and Jarinee Jongpluempiti ${ }^{2}$ \\ ${ }^{1}$ Department of Mechanical Engineering, Faculty of Technology, Udon Thani Rajabhat University, Udon Thani, Thailand 41000 \\ ${ }^{2}$ Department of Agricultural Machinery Engineering, Faculty of Engineering and Architecture, \\ Rajamangala University of Technology Isan, Nakhon Ratchasima, Thailand 30000
}

\begin{abstract}
This research aims a study to compare the thermal parameter of the original (rectangular) and circle salt boiling stove by computational fluid dynamics (CFD) of the boiling salt process in Ban Dung area, Udon Thani province. The first study, the rectangular stove has U-shaped channel for heating flow through chimney that the stove size is $2.4 \mathrm{~m}$ of width, $6.0 \mathrm{~m}$ of long, $0.8 \mathrm{~m}$ of high and cross-sectional area of heating flue was $0.8 \times 0.8 \mathrm{~m}^{2}$. The second study, the circle salt boiling stove has a similarly volume of the rectangular stove of $4.32 \mathrm{~m}^{3}$ and the diameter of $4.58 \mathrm{~m}$. From the results of mathematical models by CFD found that the rectangular stove have the thermal efficiency, the highest fired temperature and the velocity outlet of hot air of $17.78 \%, 537.77^{\circ} \mathrm{C}$ and $4.862 \mathrm{~m} / \mathrm{s}$, respectively. Then, the circle stove have $24.59 \%$, $758.32^{\circ} \mathrm{C}$ and $3.1424 \mathrm{~m} / \mathrm{s}$, respectively. it can be calculated the thermal efficiency reduce of the boiling salt production is $27.69 \%$. Comparison between the rectangular and the circle salt boiling stove found that the circle stove have the thermal efficiency and heating flue more than the rectangular stove. It can reduce the cost of production and reduce the fuel consumption in the salt boiling process.
\end{abstract}

\section{Introduction}

Northeastern region of Thailand is produced the salt area of $1,840 \mathrm{~km}^{2}$ and about $30 \%$ of the agricultural area [1]. In Udon Thani province, Ban Dung district is mainly rock salt production region about $18 \%$ of total salt production area in Thailand. The amount of rock salt reserve is 18 trillion tons [2]. Now, Ban Dung has the salt production area about $4.99 \mathrm{~km}^{2}$ and the amount of salt production is 194,500 tons/year [3]. The rock salt production, by pumping salt-water from the resource and then make the salt-water becomes crystalline (salt products) by boiling [4]. The salt boiler made from the steel plate in rectangular shape, size $2.4 \times 6.0 \times 0.3 \mathrm{~m}$. The salt boiler is placed on a salt boiling stove that the original stove made from clay in U-shaped channel, size of $2.4 \times 6.0 \times 0.80 \mathrm{~m}$., and then boiling salt by burning with firewood as a fuel until the salt-water becomes crystalline salt (salt products) [5]. For salt boiling process, there are the study to increasing the thermal efficiency of fuel and reducing the cost of salt boiling. If the salt boiling stove can be reduce the cost of firewood fuel that can increase the profitability of the salt production as well. If the salt boiling stove is more than higher thermal efficiency that can be reduced the amount of firewood in the salt boiling process and the conservation of forest resources in the future. From the study showed that the original salt stove was low efficiency, so it was used to amount of fuel was large quantities and the high cost of production.
Therefore, the mathematical model was used to analyze increasing the thermal efficiency of salt boiling stove. The design of the new salt boiling stove is different to the original which the new salt boiling stove is circle salt boiling stove. However, the same feature of both stoves is the volume of salt-water used for boiling is $4.32 \mathrm{~m}^{3}$. Then, the stoves have been analyzed by computational fluid dynamics (CFD) program to compare thermal parameter and analysis to find ways to reduce the fuel cost of boiling salt process between the original (rectangular) and circle salt stove.

\section{The combustion salt boiling equation}

\subsection{The computational fluid dynamics}

Computational fluid dynamics (CFD) is analyzing fluid flow behavior [6]. Currently, CFD is critical to analyzing fluid flow behavior whether it is speed, pressure and temperature. There are three components as; partial differential equations, boundary conditions and geometry. The analysis is based on the equation of Reynolds-averaged Navier-Stokes equation can be expressed as (1).

$$
\rho \bar{u}_{j} \frac{\partial \bar{u}_{i}}{\partial x_{j}}=\rho \bar{f}_{i}+\frac{\partial}{\partial x_{j}}\left[-\bar{p} \delta_{i j}+\mu\left(\frac{\partial \bar{u}_{i}}{\partial x_{i}}+\frac{\partial \bar{u}_{j}}{\partial x_{i}}\right)-\rho \overline{u_{i}^{\prime} u_{j}^{\prime}}\right]
$$

\footnotetext{
* Corresponding author: saphichat $@$ udru.ac.th
} 
Eq. (1) is solved by the mass conservation equation, momentum conservation equation and energy conservation equation [7]. Eq. (1) is solved by the mass conservation equation, momentum conservation equation and energy conservation equation [7].

\subsection{The combustion salt boiling process}

The combustion salt boiling process equation that used to analyze the initial heat transfer is the internal energy can be expressed as Eq. (2). The heat flux for the system and the heat flux emitted from the system can be calculated from Eq. (3) [8].

$$
\begin{gathered}
\Delta Q=\frac{\Delta E}{V} \\
\Delta q=\frac{\Delta Q}{A}
\end{gathered}
$$

The equation used to estimate the difference in pressure between inlet pressure and outlet pressure can be calculated from Eq. (4) [9].

$$
\Delta P=\operatorname{Cah}\left(\frac{1}{T_{o}}-\frac{1}{T_{i}}\right)
$$

\section{Model and hypothesis}

\subsection{The model of salt boiling stove}

The original salt boiling stove in Ban Dung of salt production was U-shaped channel burner size of $2.4 \mathrm{x}$ $6.0 \times 0.8 \mathrm{~m}$ that made from clay and the firewood used in boiling salt process was a rubber wood from sawmills industrial. The model of rectangular salt stove is a Ushaped channel burner size of $2.4 \times 6.0 \times 0.8 \mathrm{~m}$ and cross-sectional area of heating flue was $0.8 \times 0.8 \mathrm{~m}^{2}$, as shown in Figure 1(a). The model of circle salt stove is developing for increase the thermal efficiency that the diameter of stove is $4.58 \mathrm{~m}$. and the high of $0.3 \mathrm{~m}$., as shown in Figure 1(b). A study to the thermal efficiency of salt boiling stove is calculating the related thermal energy by using the similarly conditions and mathematical model.

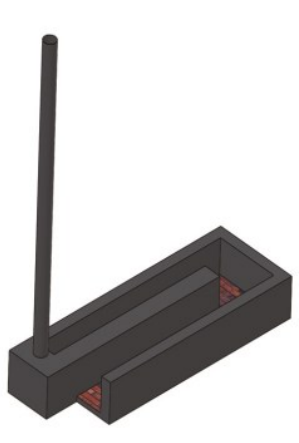

(a) The rectangular salt stove

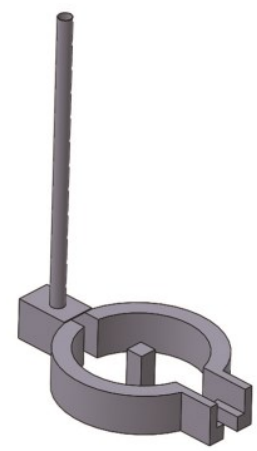

(b) The circle salt stove
Fig. 1. The model of salt boiling stove use for analyzing

\subsection{The hypothesis of salt boiling stove}

Mathematical model has been used to compare the thermal efficiency between the rectangular and the circle salt boiling stove using CFD analyze. The conditions of model consists of; the steady state condition, the fluid used in the analysis is air at ambient temperature, density of air is $1.225 \mathrm{~kg} / \mathrm{m}^{3}$, specific heat $(\mathrm{Cp})$ of air is $1,006.43$ $\mathrm{J} / \mathrm{kg}-\mathrm{K}$, using standard $\mathrm{k}$-epsilon equation to predict fluid turbulence of analysis, the heat source (calculated from the thermal energy of the fuel, the mass of the fuel per total time for test) of $22,500 \mathrm{~W}$, the air inlet is exposed to atmospheric pressure, the air outlet is a difference in pressure of 30 psi with the air inlet, the pressure difference between the inlet pressure and the output pressure $(\mathrm{Pa})$ is the constant a value of $0.0342 \mathrm{~K} / \mathrm{m}$ [10], and the lose heat of the surface sink in salt boiling process (calculated from the rate of heat loss to salt in the area) of $2,500 \mathrm{~W} / \mathrm{m}^{3}$. Then, it can be simulated with CFD to compare the thermal parameter between the rectangular and the circle salt boiling stove.

\section{Results}

\subsection{The temperature of salt boiling stove}

From the models, it was found that the temperature of the circle salt stove has a higher average temperature than the rectangular salt stove. The heat dissipation of the rectangular salt stove is uniform that the inlet area has a higher temperature and reduced by the distance in the stove to the chimney, as shown in Figure 2. Similarly, the circle salt stove has a uniform heat dissipation but it is higher more than rectangular stove, as shown in Figure 3.

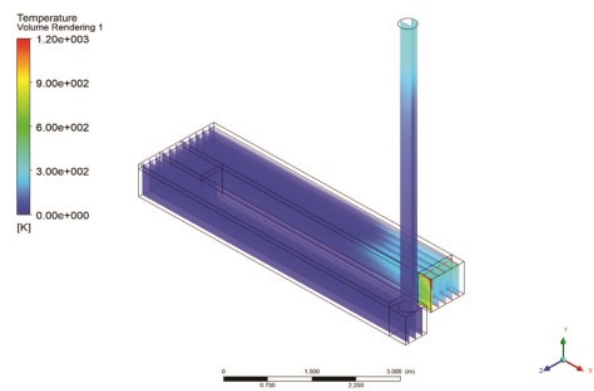

Fig. 2. The temperature of the rectangular salt boiling stove
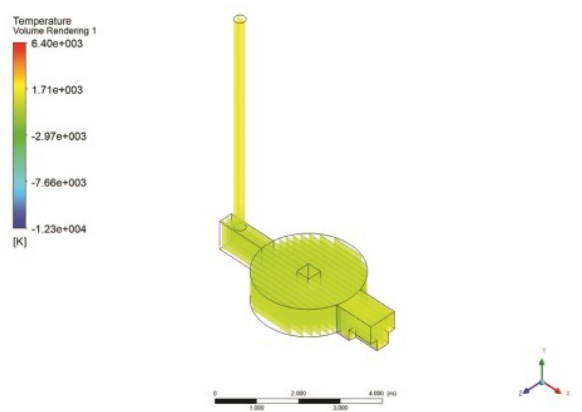

Fig. 3. The temperature of the circle salt boiling stove 


\subsection{The air flow velocity of salt boiling stove}

From the models, it was found that the hot air flow velocity of the circle salt stove was a higher than the rectangular salt stove, but the hot air flow velocity values have a similar. The air flow velocity profiles were shown in Figure 4 and 5, respectively. However, the circle salt stove causes the hot air to circulate inside the stove rather than the rectangular stove. The hot air of rectangular stove will flow through the channel to the chimney. This is the result that the hot air flow velocity of the circle salt stove was a higher.
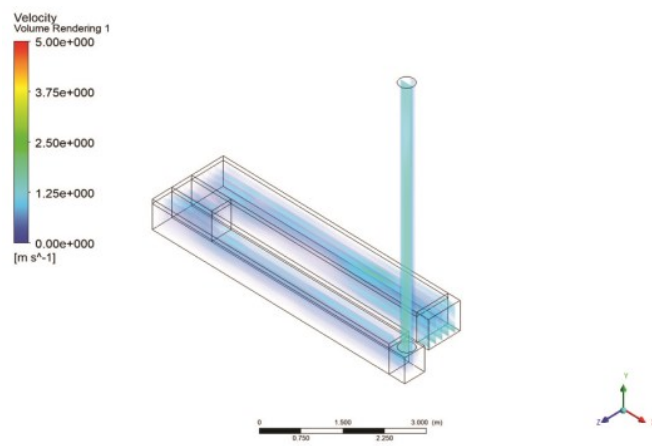

Fig. 4. The hot air flow velocity of the rectangular salt boiling stove
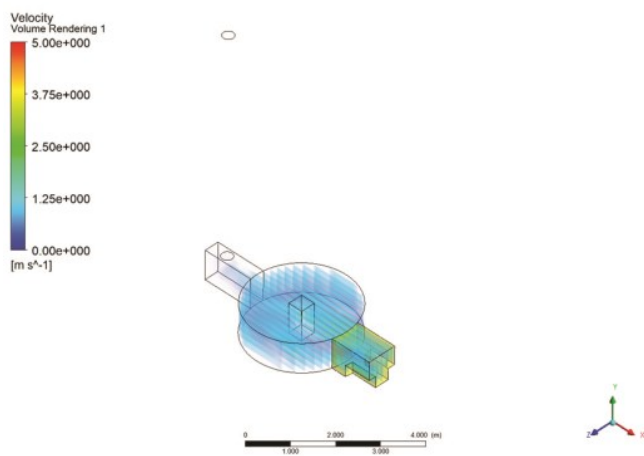

Fig. 5. The hot air flow velocity of the circle salt boiling stove

\subsection{The pressure of salt boiling stove}

When, the air flow of the circle stove is lower speed and the hot air circulate inside the stove that cause to the pressure of circle salt stove is higher than rectangular salt stove. The circle salt boiling stove has higher pressure more than the rectangular salt boiling stove. The pressure distribution profiles of the salt stoves were shown in Figure 6 and 7, respectively.

\subsection{The comparison efficiency of salt boiling stove}

From the thermal efficiency calculation of the rectangular and the circle salt boiling stove, it can be seen in Table 1. The rectangular salt stove has a thermal efficiency of $17.78 \%$, but the circle salt stove has a thermal efficiency of $24.59 \%$. It is evident that the thermal efficiency of the circle salt stove is greater than the rectangular salt stove. It can reduce amount of fuel consumption and heating energy consumption by $27.69 \%$.
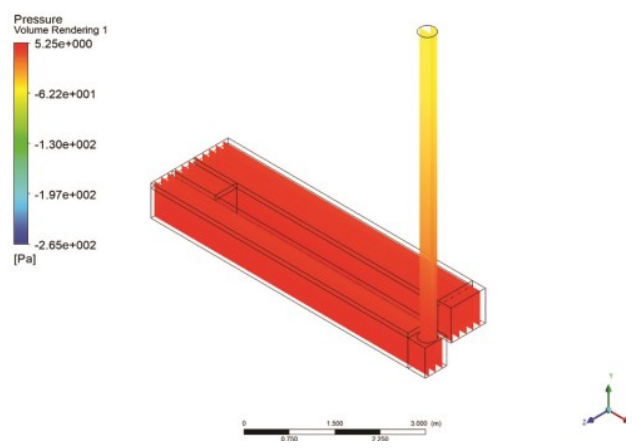

Fig. 6. The pressure distribution of the rectangular salt boiling stove
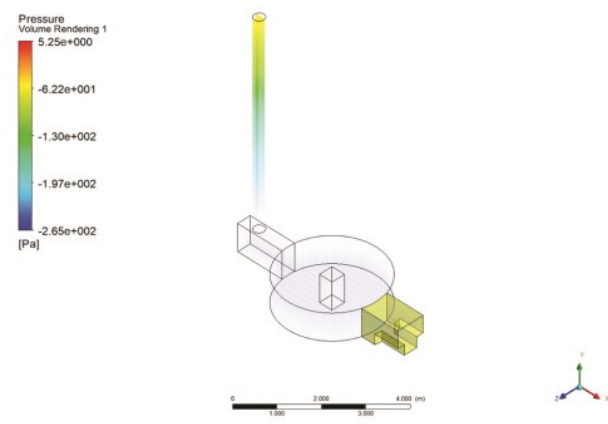

Fig. 7. The pressure distribution of the circle salt boiling stove

Table 1. Comparison of salt boiling stove efficiency (average).

\begin{tabular}{|c|c|c|c|}
\hline Type of salt boiler & $\begin{array}{c}\text { Heat } \\
\text { input } \\
\text { (MJ) }\end{array}$ & $\begin{array}{c}\text { Heat } \\
\text { Utilization } \\
\text { (MJ) }\end{array}$ & $\begin{array}{c}\eta \\
\text { (\%) }\end{array}$ \\
\hline Rectangular salt stove & 28.95 & 5.15 & 17.78 \\
\hline Circle salt stove & 28.95 & 7.12 & 24.59 \\
\hline
\end{tabular}

\subsection{The parameter result for CFD}

From the mathematical model results, it can be seen that the hot air temperature inlet of the rectangular salt stove and the circle salt stove were similar of $300 \mathrm{~K}\left(27^{\circ} \mathrm{C}\right)$ and the hot air temperature outlet of the rectangular salt stove and the circle salt stove were $1,239.16 \mathrm{~K}$ $\left(966.16^{\circ} \mathrm{C}\right)$ and $1,432.34 \mathrm{~K}\left(1,159.34^{\circ} \mathrm{C}\right)$, respectively. Also, the results shown that the air chamber temperature of the circle salt stove is higher than the rectangular salt stove, the average temperature within the rectangular and circle salt boiling stove is $810.77 \mathrm{~K}\left(537.77^{\circ} \mathrm{C}\right)$ and $1,031.32 \mathrm{~K}\left(758.32^{\circ} \mathrm{C}\right)$, respectively. The inlet mass flow rate of the circle stove is lower than the rectangular stove of 0.432 and $0.535 \mathrm{~kg} / \mathrm{s}$, respectively. The air outlet velocity of the circle stove is lower than the rectangular stove is 3.124 and $4.86 \mathrm{~m} / \mathrm{s}$, respectively. The pressure of the rectangular and circle salt boiling stove is -0.372 and $-0.232 \mathrm{~Pa}$, respectively. From the result of the inside air flow velocity, the circle salt stove was reduced the air flow velocity and increased the pressure. When considering the value of temperature of pan area that transfer heat between the salt stove into salt boiler, the result shown that the temerature of pan area of the circle salt stove is higher than the rectangular salt stove of $1,254.32 \mathrm{~K}\left(981.32^{\circ} \mathrm{C}\right)$ and $739.69 \mathrm{~K}\left(466.69^{\circ} \mathrm{C}\right)$, 
respectively. From the result that it causes the heat for the circle salt stove is quickly generate and the heat time period is longer than the rectangular salt stove. From that reaon, it will reducing the fuel as firewood for boiling salt process. CFD analysis can be showed in Table 2.

Table 2. Analysis results by CFD.

\begin{tabular}{|c|c|c|}
\hline \multirow[b]{2}{*}{ Parameter [unit] } & \multicolumn{2}{|c|}{ value } \\
\hline & $\begin{array}{c}\text { Rectangular } \\
\text { stove }\end{array}$ & $\begin{array}{l}\text { Circle } \\
\text { stove }\end{array}$ \\
\hline $\begin{array}{l}\text { 1. Air temperature inlet } \\
{\left[\mathrm{K},{ }^{\circ} \mathrm{C}\right]}\end{array}$ & $\begin{array}{c}300 \\
27\end{array}$ & $\begin{array}{c}300 \\
27\end{array}$ \\
\hline $\begin{array}{l}\text { 2. Air temperature } \\
\text { outlet }\left[\mathrm{K},{ }^{\circ} \mathrm{C}\right]\end{array}$ & $\begin{array}{l}1,239.16 \\
966.16\end{array}$ & $\begin{array}{l}1,432.34, \\
1,159.34\end{array}$ \\
\hline $\begin{array}{l}\text { 3. Air chamber } \\
\text { temperature }\left[\mathrm{K},{ }^{\circ} \mathrm{C}\right]\end{array}$ & $\begin{array}{l}810.77 \\
537.77\end{array}$ & $\begin{array}{c}1,031.32, \\
758.32 \\
\end{array}$ \\
\hline $\begin{array}{l}\text { 4. mass flow rate of } \\
\text { inlet }[\mathrm{kg} / \mathrm{s}]\end{array}$ & 0.535 & 0.432 \\
\hline 5. Velocity inlet $[\mathrm{m} / \mathrm{s}]$ & 0.780 & 0.654 \\
\hline 6. Velocity outlet $[\mathrm{m} / \mathrm{s}]$ & 4.862 & 3.124 \\
\hline 7. Furnace pressure $[\mathrm{Pa}]$ & -0.372 & -0.232 \\
\hline $\begin{array}{l}\text { 8. Pressure of heat } \\
\text { Source }[\mathrm{Pa}]\end{array}$ & -0.374 & -0.234 \\
\hline $\begin{array}{l}\text { 9. Temperature of pan } \\
\text { area }\left[\mathrm{K},{ }^{\circ} \mathrm{C}\right]\end{array}$ & $\begin{array}{l}739.69 \\
466.69\end{array}$ & $\begin{array}{c}1,254.32 \\
981.32\end{array}$ \\
\hline
\end{tabular}

\section{Conclusion}

This research is a mathematical model for the analysis of the thermal efficiency of salt boiling stove using firewood as fuel that is analyze by computational fluid dynamics (CFD) to compare thermal parameter and analysis to find ways to reduce the fuel cost of boiling salt process between the rectangular and circle salt stove. The salt boiling stove in Ban Dung, Udon thani Province is U-shaped channel salt boiling stove that size of $2.4 \mathrm{x}$ $4.0 \times 0.8 \mathrm{~m}$ and the volume of salt-water used for boiling is $4.32 \mathrm{~m}^{3}$. The new salt boiling stove is the circle salt stove has the diameter of $4.58 \mathrm{~m}$., the high of $0.3 \mathrm{~m}$. and the volume is similar with rectangular stove. The experiment found that the output air temperature of the circle stove is higher than the rectangular stove. The chamber temperature of the salt stove is $810.77 \mathrm{~K}$ $\left(537.77^{\circ} \mathrm{C}\right)$ and $1,031.32 \mathrm{~K}\left(758.32^{\circ} \mathrm{C}\right)$, respectively. The outflow velocity of the improvement stove is lower than the original stove of 3.124 and $4.86 \mathrm{~m} / \mathrm{s}$, respectively. The pressure in the salt stove is -0.372 and $-0.232 \mathrm{~Pa}$, respectively. For the circle salt stove found that the air flow velocity is decreases and the pressure is increases. The temperature of pan area of the circle salt stove is higher than the rectangular salt stove of $1,254.32 \mathrm{~K}$ $\left(981.32^{\circ} \mathrm{C}\right)$ and $739.69 \mathrm{~K}\left(466.69^{\circ} \mathrm{C}\right)$, respectively. The rectangular salt stove has a heat input of $28.95 \mathrm{MJ}$, a heat utilization of $5.154 \mathrm{MJ}$ and the thermal efficiency of $17.78 \%$. And then, the circle salt stove has a heat input of $28.95 \mathrm{MJ}$, a heat utilization of $7.12 \mathrm{MJ}$ and the thermal efficiency of $24.59 \%$. It can be seen that the thermal efficiency of the circle salt stove is more valuable than the rectangular salt stove. As a result, it can be reduce the fuel as firewood and can be calculate the higher thermal energy of $27.69 \%$, which can benefit the salt industry. If the salt producers want to reduce cost of production and reduce the fuel consumption in the salt boiling process, they should be use the circle stove for the salt production process.

\section{Acknowledgements}

The authors acknowledge the grant from Udon Thani Rajabhat University that financially supported in this paper. The authors are also grateful to the Pipatpong Boil Salt in Ban Dung for supporting the tools and equipment used in this research.

\section{References}

1. P. Buangnawa. Report - Strategic planning for the development saline soil area at north-eastern of thailand. (Land Development Department, Ministry of agriculture and Coorperatives, Bangkok, Thailand, 2015)

2. R. Phruchayawaranon. Environmental Management in Salt Production Area, Ban Dung, Udon Thani. (Thesis Master of Science, Department of Resource management, Kasetsart University, Thailand, 2012)

3. N. Sirithongkam. Report - Project of Saline Soil Development in the North-Eastern Area (Phase 2: Expansion), Udon Thani Province. (Department of Mineral Resources, Ministry of Industry, Thailand, 2012)

4. National Science and Technology Development Agency. Salt more salty. (National Science and Technology Development Agency, Ministry of Science and Technology, Thailand, 2012)

5. A.Srichat, P.Vengsungnle and A.Bootwong. A Study to increasing the thermal efficiency of the improvements salt boiling stove which the fuel was firewood in Ban Dung area, Udon Thani province by CFD. Energy Procedia 138, (2017)

6. J. Jongpluempiti and K. Tangchaichit. STUDY OF BEHAVIOUR THE HEAT AND FLOW IN CASSAVA RHIZOME FIRED DAN KWEAN KILNS. (Thesis Ph.D. in Mechanical Engineering. Faculty of Engineering. Khonkaen University. Thailand, 2013)

7. Bichkar, P., Dandgaval O., Dalvi P., Godase R and Dey T. Study of Shell and Tube Heat Exchanger with the Effect of Types of Baffles. Procedia Manufacturing, 20, (2018).

8. Cengel Y. A. and Ghajar A. J. Heat and Mass Transfer (5th ed.). (United States: McGraw-Hill Education, 2014)

9. Pei P., Ouyang M., Feng W., Lu L., Huang H., and Zhang, J. Hydrogen pressure drop characteristics in a fuel cell stack. International Journal of Hydrogen Energy. (2006)

10. Guo P., Li J., Wang Y. and Wang, Y. Evaluation of the optimal turbine pressure drop ratio for a solar chimney power plant. Energy Conversion and Management. (2016) 